\title{
SOCIAL SECURITY MARKETING AND NATIONAL DEVELOPMENT
}

\author{
${ }^{1}$ Dr. Igwe, Sunny Rukani \\ Department of Marketing,Faculty of Management Sciences, \\ University of Port Harcourt,Choba, Port Harcourt,Nigeria. \\ ${ }^{2}$ Dike, Mercy Onyinyechi \\ Department of Marketing, Faculty of Management Sciences, \\ University of Port Harcourt, Choba, Port Harcourt, Nigeria.
}

Article DOI: https://doi.org/10.36713/epra4657

\begin{abstract}
Bridging the gap between the trodden poor and the rich has always posed a perennial challenge and this requires the marketing of social security for all concerns by the government. Social security has been a catalyst to the economic and national development of nations of the world. This explains why the Nigerian economy has been subjected to modernization efforts as newer schemes are springing up. Through exploratory and critical review design, this paper examined social security marketing and explored how its practices would enhance national development by improving and balancing the living standard of the poor. Finally, it encourages that adequate and timely adoption of social security marketing is a driver for national development.
\end{abstract}

KEYWORDS: Social security, National Development, Disability scheme, Marketing

\section{INTRODUCTION}

One mandate of every government is to provide social security. Several laws, constitutions, Charters and Summit e.g. International Labour Organization (ILO), Magna Charter and the World Summit in Copenhagen in 1995 for Social Development, anchored more on social security system as a catalyst and an essential ingredient of equitable social development and the fight against poverty. Social security involves all regulations to secure physical safety and give comprehensive protection, to minimize risks that will effect individuals or group of individuals without relying on external aid (Kasente, 1998).

Social security cover mostly the most vulnerable, the poor, handicapped, disabled, children, women, pensioner/retiree, aged, widowhood, able but unemployed youths, etc. Social Security is a critical program that promotes income stability and redistribution among households, steady streams of income to replace wages lost due to retirement, disability, and or death thereby fostering standard of living and national development. The theoretical question has always being how effective is the private sector, individual and government at all levels creating and regularly promoting protection against any unexpected external circumstances such as old age, risky political changes, economic shocks, health complication and death (Koptis, 2013).

The solution to and the meaning of the concept of development is multidimensional, as there are varied stages of development in different countries. Generally, development connotes fair, equitable distribution, and access of resources arising from growth. Apart from economic, infrastructural, political developments, we conceptualize here and dwell more on social development as sustainable 


\section{EPRA International Journal of Research and Development (IJRD)}

Volume: 5 | Issue: 6 | June 2020

- Peer Reviewed Journal

protection, stream income and livelihood of the poor. So this paper addresses development on sustainable standard of living of the poor.

To guarantee development through social security; a formal, sincere and concerted, social data profiling, promotion, distribution and implementation of the various social security package are needed in social security marketing. Social security marketing is the use of marketing theory, skills and practices to achieve social change; its primary goal is achieving social equity for the common good as against traditional commercial marketing but may equally have positive social effects (Diamond, 2006).

Social security marketing seeks to develop and integrate marketing concepts with other approaches to social change, modification of attitude and behavior towards redistribution of common resources and protection of the poor. Social security marketing aims to influence behaviors that benefit individuals and communities for the greater social good; it enables the delivery of competition-sensitive and segmented social change programs that are effective, efficient, equitable and sustainable. Beneficiaries of social security government and private sector includes, persons with disabilities, social insurance, health insurance (including medical care and medical rehabilitation), pension scheme, social rehabilitation, professional rehabilitation along with employment of persons with disabilities, social assistance.

More so, the pride of any government is the attainment of higher value level of development in such a way that its citizens would derive natural attachment to governance (Ogwumike, 2005). Previous studies on social security marketing has been applied to government policies of different kinds of social risks including unemployment, retirement, health, disability, pension schemes (Butter et al., 2003). However, to date, scarce research has considered a newly introduced social security known as N-power; this became imperative as there is high level of unemployment and this scheme caters for youth empowerment, additionally, disability scheme is captured in this study because there exist quite a large number of deformed people roaming round the street. Thus, this study make a robust explanatory and theoretical expansion of social security and relates same to national development unlike previous studies. It is on this narrative that this paper seeks to ascertain the connection between social security marketing and national development in Nigeria.

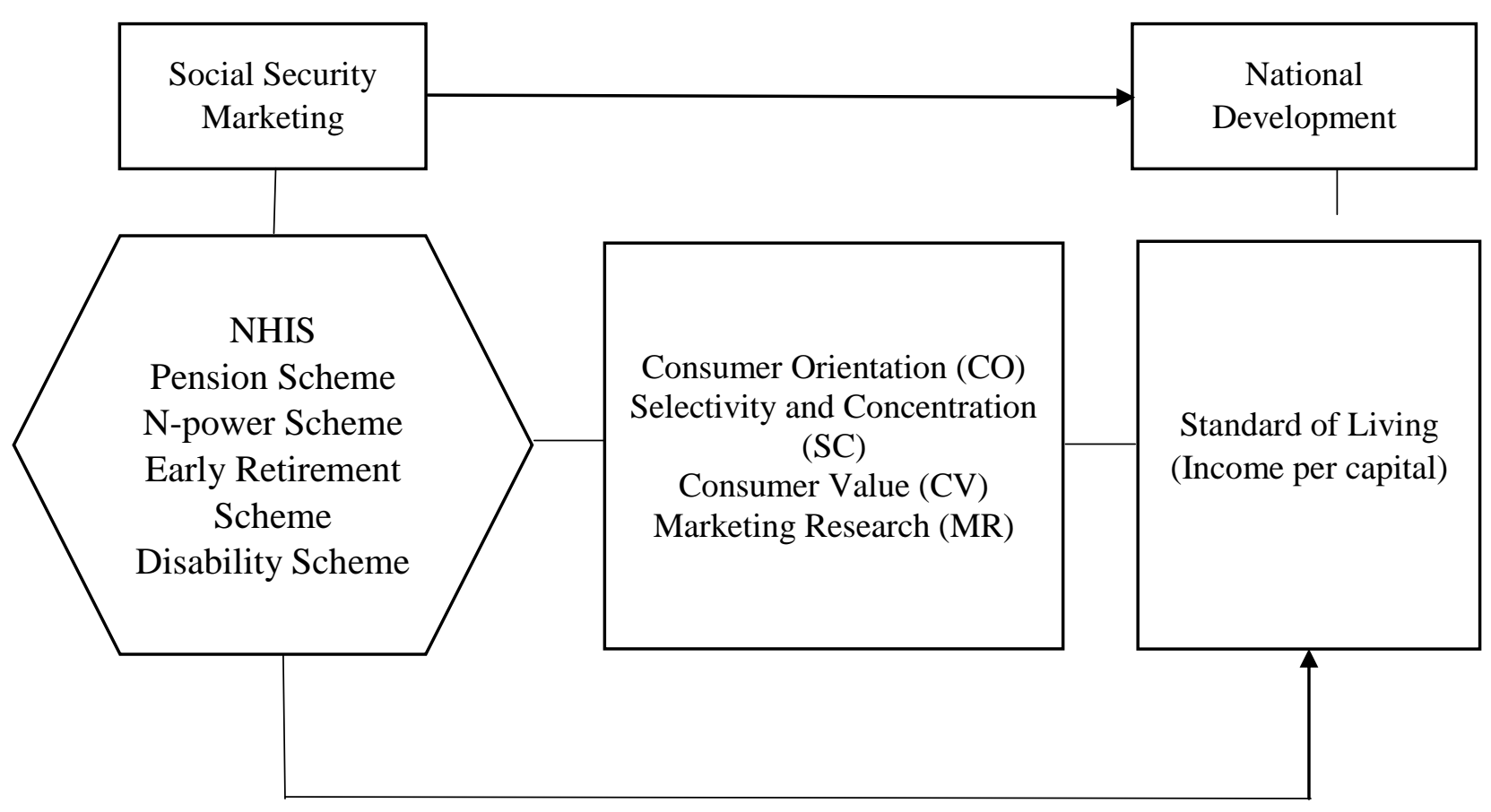

Fig 1: Conceptual Frame work of Social Security and National Development 


\section{THEORETICAL FOUNDATION Social Learning Theory}

Rotler (1954), developed the social learning theory and pointed out that in understanding behavior, one must take both the individual (i.e. his or her life history of learning and experience) and the environment (those stimuli that the person is aware of and responds to) into account. Rotler sees behavior as always changeable. This theory is also premised on the fact that people learn new behavior through overt reinforcement or punishment and reward. If people observe positive, desired outcomes in the observed behavior, they are more likely to model, imitate and adopt the behavior themselves. Thus, the citizens must learn and be aware of the social security programs provided by the government, their thinking pattern and right to life should be changed and pursued in order to embrace the reinforcement value therein.

\section{Social Protection Theory}

Social protection theory also lend credence to safety and protection of workers from hazard and security from all their lost labour. As expanded, ILO Convention social protection encompasses social security policies aimed at protecting workers from social risks. The convention identifies nine areas in which must be included in the provision of social security: medical care, unemployment, old age, employment, injury, family, maternity, invalidity and survivors' benefits. It also establishes the minimum level of benefits to be provided.

Social protection refers to the public actions taken in response to levels of vulnerability, risk and deprivation which are deemed socially unacceptable within a given society. Lund \& Srinivas (2000) posits, social protection has the same encompassing tenor or umbrella sense as social security, its advantage over social security is that it is being extensively used in both 'more developed' and 'less developed' parts of the world. Van \& Wouter (2000), distinguishes these two components of social protection as follows: Social assistance which refers to the benefits in cash or in kinds that are financed by the state (national or local) and that are mostly provided on the basis of a means or in context and Social insurance seen as social security that is financed by contributions and is based on the insurance principle. The essence of insurance is understood here to be the elimination of the uncertain risk of loss for the individual or household by combining a larger number of similarly exposed individuals or households into a common fund that makes good the loss caused to any member (Van \& Wouter, 2000). Thus, it is the right of citizens to be protected by the government which emphasizes the need for adequate marketing of social securities.

\section{Social Security}

Sighn (2004), posits social security refers to the action programs of an organization intended to promote the welfare of the population through assistance measures guaranteeing access to sufficient resources for food and shelter and to promote health and well-being for the population at large and potentially vulnerable segments such as children, the elderly, the sick and the unemployed. Clearly, the main intention of introducing social security is to ensure a continuous flow of income for the needy, indigent, less privileged and pensioner. Social security is also seen as a mechanism to reduce unemployment and to achieve labor market equilibrium (Alderman et al., 2009).

Many advanced country have new look social security, to create a more positive attitude not just too structural and technological change, but also to the challenges of globalization and to its potential benefits in terms of greater efficiency and higher productivity (Gboyemi, 2003). Countries with relatively open national economies (a high ratio of trade to GDP) and high exposure to external risks (high variability in the relative prices of imports and exports) have been observed to provide high levels of social security. It appears that societies which expose themselves to more external risk demand a higher degree of social protection. Thus there is a symbiotic and mutually reinforcing between globalization and social security (Koptis, 2013).

Furthermore, Leliveld (2001) opined, Social security is the protection, by society, of individuals or social groups against a fall in their standards of living. The Relevance of Social Security is felt on economic development of temporary adversities, and the amelioration, by society, of those standards of living of individuals or social groups which are below an acceptable minimum level. In Nigeria some of these social security schemes are worth mentioning

\section{National Health Insurance Scheme (NHIS)}

Health insurance is a social security system that guarantees the provision of needed health services to persons on the payment of token contributions at regular intervals. The National Health Insurance Scheme (NHIS) is a corporate body established under Act 35 of 1999 by the Federal Government of Nigeria to improve the health of all 
Nigerians at an affordable cost. Given the general poor state of the nation's health services and the excessive dependence and pressure on Government owned health facilities, with the dwindling funding of healthcare in the face of rising cost, the Scheme is designed to facilitate fair and joint financing of health care costs through pooling and judicious utilization of financial risk protection and cost-burden sharing for people, against high cost of health care through institution of prepaid mechanism, prior to their falling ill. This is in addition to the provision of regulatory oversight on Health Maintenance Organizations (HMOs) and Health Care Providers (HCPs). Several health insurance schemes exist around the world. The Scheme was officially launched on 6th June 2005 and commencement of services to enrollees started in September 2005. Till date, over 4 million Identity Cards have been issued, 62 HMOs have been accredited and registered. Presently, 5,949 Healthcare Providers, 24 Banks, 5 Insurance Companies and 3 Insurance Brokers have also been accredited and registered. This is worrisome when compared to our population there is urgent need to market and enforce it.

Pension Scheme

Diamond et al., (1993), suggested that social security serves the purpose of private pension plans, but is administered by the government because they enjoy the greatest economies of scale in administration costs. So, like private pension benefits, social security benefits are earnings tested, not asset tested, increasing in lifetime contributions, and are paid to emigrants and the institutionalized. And like private pension plans, retirement ages have not risen over time. Even with the introduction of pension fund administrator (PFA), how adequately is it marketed? Are retiree really getting their money as at when due both in public and private sector? Is there trust that people's contribution will not be misappropriated? Advocacy marketing and government will is needed here to promote this program

\section{N-Power Scheme}

N-Power is linked to the Federal Government's policies in the economic, employment and social development arenas. N-Power addresses the challenge of youth unemployment by providing a structure for large scale and relevant work skills acquisition and development while linking its core and outcomes to fixing inadequate public services and stimulating the larger economy. It aims at learning a skill for cash. The modular programs under N-Power will ensure that each participant will learn and practice most of what is necessary to find or create work. The N-Power Volunteer Corp involves a massive deployment of 500,000 trained graduates who will assist to improve the inadequacies in our public services in education, health and agricultural sectors. Some of these graduates will also help in actualizing Nigeria's economic and strategic aspirations of achieving food security and selfsufficiency (Stewart, 2009). N-Power is a platform for diversifying the economy. N-Power scheme prepares young Nigerians for a knowledge economy when, equipped with world-class skills and certification, they become innovators and movers in the domestic and global markets. Nigeria will have a pool of software developers, hardware service professionals, animators and graphic artists, building services professionals, artisans and others. N-Power also focuses on providing our non-graduates with relevant technical and business skills that enhance their work outlook and livelihood. The question is how reliable and sustainable is the scheme.

\section{Early Retirement Scheme}

Retirement is a process that separates an individual from a job role or as termination of a pattern of life and a transition (Holzmann R. et al., 2013). The clauses of the detachment or separation may be due to old age, poor health, social pressure or apathy. Retirement is the point where people stop employment completely.

Martin (1996) proposes that employment should be redistributed from the older generation to the younger generation. Greater employment opportunity for the younger generation will increase the nation's productivity. Hence, the package or social security received can be regarded as the price paid to employees who are ready for retirement. An effective social security system can be a fruitful partnership of manpower. Theoretically early retirement is a choice made at a person's own will after fulfilling the minimum requirement to enable the employee to receive his social security benefit, while the normal retirement is the retirement at the mandatory age (Gruber \& Wise 1998). The normal retirement age is the mandatory age where he is 'forced' to retire whether he likes it or not.

\section{Disability Scheme}

Social protection systems play a key role in meeting the specific needs of persons with disabilities with regard to income security, social health protection and social inclusion. Disability benefits are one of the elements of social protection systems that explicitly address disability-related needs and provide income support to persons with disabilities and their 
families (Asher et al., 2006). These include both contributory schemes (disability pensions), as well as non-contributory disability benefits. This scheme should be able to remove beggars, the blind, the lame, handicaps from the street.

In addition, this schemes and programs supports the integration of persons with disabilities into the labor market and facilitate their participation in employment thereby playing a key role in promoting independent living and income security. In this respect, financial support to cover the disabilityrelated costs associated with having a job can help persons with disabilities to avoid falling into poverty traps and facilitate their participation in productive employment (Locke, 2003).

\section{Marketing of Social Security.}

Most citizens are not even aware of these available social security programs and their rights and as such are denied these social security even when they exist. There is need to market and promote social security to the various stakeholders. Donovan and Owen (2004), proposed the following concepts, principles and features of marketing which apply to the social security: consumer orientation, selectivity and concentration (market segmentation), consumer value (use of the marketing mix), use of market research.

\section{Consumer Orientation Approach}

The basics of enjoying and engaging in social security is consumer orientation marketing which differs from other frameworks because its needs and campaign orientation are used to achieve social change and social benefits. Weininger (2009), argues that the consumer orientation approach is different from the approach that many public health practitioners take in the assumption that they know what is best for the public. Utilizing the marketing conceptual framework requires an understanding of the need of consumers or target audiences whose behaviors are the focus of social security marketing efforts (Grier \& Bryant, 2005). Consumer orientation implies that the consumer is central to, and an active participant in the social security marketing process. Therefore, social marketers must be aware of, and responsive to, consumer social needs and aspirations and the various segment of social security.

\section{Market (customer) Segmentation}

Market segmentation is a cornerstone of commercial marketing. Marketers divide the total population of interest into lifestyle, demographic or attitudinal segments, then select and concentrate on those segments that the company is best suited to service. Using the principle of segmentation, social security marketers tailor marketing strategies (including the products, prices, promotions and placements) that are most responsive to the needs of the different target audiences (Bryant, 2002). Social security marketers use formative research to gain an insight into wants, needs and aspirations of consumers. Segmentation of the target audience ensures maximum efficiency and effectiveness in the use of scarce resources (Andreasen, 2002) and classify the various social security programs.

\section{USE OF THE MARKETING MIX}

The 'four Ps' of the marketing mix, includes product, price, place, and promotion. Product considerations are the actual product or service as well as the brand name, reputation, packaging and so on. In social security marketing, the product is the behavior or service and security idea that the campaign planners would like the individuals (i.e. consumers) to adopt. This product/service has breadth and width e.g contribution to pension scheme, following health campaign for the aged and disability persons, widow-hood and child bearing mothers. The product must be positioned, presented and/or modified in such a way as to maximize benefits and minimize costs.

\section{Price}

In commercial marketing, price refers to the naira outlaid for the product or service. However, it also includes other costs associated with buying the product, such as transport time and foregone opportunities. In social security marketing, costs can involve sacrifices related to psychological wellbeing (e.g. increased anxiety), sociality, time lag to get payment and registration, trust (e.g. possibility of ostracism), economics (e.g. financial sacrifice) understanding of the price can be used to promote benefits for the consumer.

\section{Place}

In commercial marketing, place refers to the distribution channels used to make the product available to target audiences. However, in the marketing of social security Place includes locations or channels that provide opportunities to try and practice the behavior or to experience the service/product (Stead, 2005). When the product is a physical item, it must be easily obtainable by consumers. When it is an idea, it must be socially available and supported within the consumer's social sphere. Is this scheme well distributed in all states, local government, ward, and is it accessible? The placement of activities for specific ethnic groups is more likely to be received in areas where these 
groups congregate (e.g. products might be better received in mosque settings for Muslims and in churches for Christians.

\section{Promotion}

Promotion encompasses all the marketers' efforts to ensure that the target audience is aware of the product and its benefits, its price and where it is available. The promotional mix for social security marketing includes publicity, public relations, advertising, sales promotions and sponsorship. These promotional efforts are designed to cultivate positive attitudes and intentions regarding the product that pave the way for positive behavior. It is anticipated that a range of promotional activities (e.g. incentive, community salesforce, community development projects, multimedia information dissemination backed up with training and provider support, developing promotional strategies that enable supportive and responsive gaming policies and environments) are likely to be needed to inform citizens about this social programs. However, Booms and Bitner (1981), extends marketing mix from 4p's to 7p's adding three elements (people, physical evidence and process). The use of these elements to market social security to the citizens are further described below.

\section{People}

These are essential ingredients in service provision; recruiting and training the right staff is required. They represent the company staff and customer contact in service delivery. Many social security products are services delivered by health and other professionals (e.g. immunization, pension workers, n-power, quit smoking courses, nurses, general Practitioners, welfare workers, bureaucrats). The consumer's experience is dependent on the interaction between the 'customer' and the 'salesperson'. People drive the process, they sell the product; they are value-oriented towards service delivery. As in a commercial situation, staff should be polite, attentive, friendly, knowledgeable and well-trained to deliver the service; thus ensuring a satisfying experience and hence repeat purchase or favorable word of mouth about the government of the day. The delivery of social service by NHIS for instance, people (health staff) are considered of particular importance as the service depends on the nature of the relationship between the citizens and health providers; thus, government should improve on staff's competence and appearance.

\section{Physical Evidence}

This is a vital component of the service delivery process by which the firm can provide tangible object to customers (Lovelock, 2001). It entails where this services are provided and delivered from, their offices, ambience, location, accessibility (the closer it is to customers, the better), the contact of the store, etc. In order to make social security available to the populace, the government should ensure that the physical evidence appearance from where these services are delivered are being improved.

\section{Process}

According to Gronroos (2000), process is the most sensitive and critical activity in service delivery. It is the expressive performance of a service, process is described through duration (total time involved before and during the service encounter), bureaucratic nature, service delay, number of documentation involved, assurance and employee effort (the skills, knowledge and professionalism of customer contact), customer participation (customer's own style of consuming the product), waiting time, bottle necks in getting these services, etc. Processes looks at the systems used to deliver services. Thus, in the delivery of efficient social security to the citizens, government should ensure that all services are under pinned by clearly defined and effective processes.

\section{USE OF MARKETING RESEARCH}

Marketing research is the function that links an organization to its market through the gathering of information; here data profiling, analysis, capturing for all state, local government is generated. This information allows for the monitoring of all levels of social security marketing performance and improved understanding of the customers (Hair et al, 2000). Through this medium, government can determine the social security needs of its citizens in order to ensure their social wellbeing. This is where Nigeria is lacking and yet to get a comprehensive data of disability, pensioners and retiree security budget etc.

\section{National development}

Gboyega (2003) posits, development is an idea that embodies all attempts to improve the conditions of human existence in all ramifications. It implies improvement in material well-being of all citizens, not just for the most powerful and rich alone, in a sustainable way. It also demands that poverty and inequality of access to the good things of life be removed or drastically reduced as it seeks to improve personal, physical security and livelihoods and expansion of life chances.

Naomi (1995), asserts that national development is usually taken to involve not only economic growth, but also some notion of equitable 
distribution, provision of health care, education, housing and other essential services all with a view to improving the individual and collective quality of life. National development therefore can be described as the overall development or a collective socioeconomic, political as well as religious advancement of a country or nation. This is best achieved through development planning, which can be described as the country's collection of strategies mapped out by the government.

National Development Plan policy in priorities area of agriculture, industry, transport, manpower, defense, electricity, communication, education, politics, water supply and provision of social services and security (Ogwumike, 1995). Chrisman (2008), views national development as a process of societal advancement where improvement in the well-being of people are generated through strong partnerships between all sectors, corporate bodies and other groups in the society. It is reasonable to know that national development is not only an economic exercise, but also involves both socio-economic and political issues and pervades all aspects of societal life as well as improving standard of living. National development guides against worsening of citizen's living conditions which is brought on by life's contingencies that cannot be overcome by the individuals themselves (Von Hauff et al., 1997). We agree and posits that social development is as important as economic growth.

\section{Empirical Reviews of social security and National Development}

Tungazara and Maghimbin (2002), carried out a study on social security systems and national development. The study examined the nature and forms of social security in a historical perspective. It shows that nonconventional social security instruments have failed to promote equitable economic growth and have been heavily biased in favor of the well-off at the expense of the poor. The effectiveness of traditional and informal social security systems has been impaired by changes that have taken place since the colonial period. Former social security schemes are riddled with problems, the development of former social security has been gradual and the introduction of structural adjustment programs has led to the decline of these social security schemes. Gruber and Wise (1998), in their study confirms that social security plays a role in stabilizing economic development because it stabilizes demand for consumer goods by making it constant. Furthermore, Connolly and Monroe (1999), in their study classified social security as a saving concept, thus compulsory saving provides social protection for individuals not only for retirement pensions, but also for contingencies such as unemployment, disability and health problems. There is a strong evidence that social security influence national development in developed countries. However, the implementation is restricted as a result of these challenges: poor research and data profiling and documentation, lack of coordination among executive authorities, design faults in various schemes, corruption and embezzlement, absence of promotional campaigns, Inadequate cash or in-kind assistance, low distribution and coverage, high administrative costs, non-regular payment, program overlap and duplication, poor mechanisms, political interference and bureaucracy, lack of monitoring and supervision (Voruba 1998; Jamal 2010).

Methods

In study of this nature which is exploratory, we adopted a critical theoretical analysis and review of literatures, focus group discussion of two sets of seventeen post graduate students and some lecturers in marketing departments were also adopted. Our choice is as a result of the literacy and knowledge level of our focus group.

\section{CONCLUSION AND IMPLICATION}

This study has shown an exploratory as well as an appraisal of the need for social security marketing in relation to national development. Our study through the discussions has revealed that the living conditions of the poor citizens will improve if social security schemes are put in place and functional as well as being adequately marketed to the less privileged and target market in the society. It has demonstrated how the income inequality between rich and the poor can reduce through social security marketing. More so, the availability and importance of social securities should be well communicated to the citizens. Our study has also made an insight in the significance of marketing of social security; it has further reiterated and invoked the need of governments to carry on with their mandate / business of the day which is to provide social protection and securities to the citizenry especially the poor. This can be achieved through effective marketing of social security for national development. Therefore, the study recommends that everyone should think and act social security marketing, as it is a sure way to national development. 


\section{REFERENCES}

1. Alderman, H. \& Christana, P. (1995). Do the Poor Insure? A Synthesis of the Literature on Risk and Consumption in Developing Countries. Economics of a Changing World, New York: 4878.

2. Andresen, $R$. (2002). The State and the growth/Development Agenda: Africa and Issues in Nigerian Government and Politics. Ibadan, Dekaal Publisher.

3. Asher, M. \& Nandy, A. (2006). Governance and Regulation of Provident and Pension Schemes. Edward Elgar.

4. Baker, D. (2006). Public Action for Social Security: Foundations and Strategy.

5. Booms, B. \& Bitner, M. (1981). Marketing strategies and organization structures for service firms. In James Donnelly \& William George (Eds.), Marketing of services conference proceeding. Chicago: USA, 46-51.

6. Chrisman, J. (2008): Social Security for the Informal Sector: Issues, Options and Tasks Ahead. Working Paper. ILO.

7. Connolly, G. \& Monroe, S. (1999). Economics of Public Sector, Prentice Hall. Europe.

8. Diamond, P. (1993). Privatization of Social Security: Lessons from Chile, National Bureau of Economic Research.

9. Diamond, P. (1996). Proposals to Restructure Social Security. Journal of Economic Perspective 10(3), 67-88

10. Donovan, S. \& Owen (2004). A Risky Strategy: Reflections on the World Bank Report. International Social Security Review.

11. Gboyega, A. (2003). Democracy and Development: The Imperative of Local Governance. An Inaugural Lecture, University of Ibadan.

12. Grier, S. \& Bryant, C. (2005). Social Security in Developing Countries: What, Why, Who, and How? Wider Studies in Development Economics. Oxford: Clarendon, 316-339.

13. Gronroos, C. (2000). Service management and marketing. A customer relationship management approach. Chichester: Wiley \& Sons.

14. Gruber, J. \& Wise, D. (1998). Social Security in Developed Countries. Journal of Public Economics, 78: 25-49.

15. Holzmann, R., Dorfman, M., O'keefe, P, Wang, D., Sin Yvonne \& Hinz, R. (2013). Pension Reform in Europe: Process and Progress, Washington DC: The World Bank.

16. Jamal, H. (2010). A Profile of Social Protection in Pakistan: An Appraisal of Empirical Literature Research Report No

17. Kasente, D. (1996). Gender and social security reform in Africa. International social security review, 53(3): 27-41.
18. Koptis, E. (2013). Between Kinship and the State: Social Security Law in Developing Countries. The Quarterly Journal of Economics. Cambridge MIT Press.

19. Leliveld, A. (1991). An expedition in the jungle of social security in developing Countries: The search of a definition. Tübingen Institute Research Bulletin.

20. Locke J. (2003). Two Treatises of Government and a Letter Concerning Toleration. New Haven, CT: Yale University Press.

21. Lovelock, C. (2001). Service marketing people, technology, strategies $\left(4^{\text {th }} \mathrm{Ed}\right)$. Prentice Hill.

22. Lund, F. \& Srinivas, S. (1999). Learning from experience: a gendered approach to social protection for workers in the informal economy. International Labour Organization, (ILO/STEP), Geneva, Switzerland.

23. Martin, S. (1996). Uncertainty and the Welfare Economics of Medical Care. American Economic Review 53 (5), 941.

24. Naomi, O. (1995). Towards an Integrated View of Human Rights. Journal of Sociology, Nigerian National Health Insurance Scheme (NHIS): an overview. Available from [accessed Sep 09 2018]

25. Ogwumike, F. (2005). The Effects of Macro level Government Policies on Rural Development and Poverty Alleviation in Nigeria.

26. Rotler, J. (1954). Social Learning and Clinical Psychology. New York: Prentice. Hall.

27. Sighn, J. (2004). The Economics of Rural Organizations: Theory, Practice and Policy. New York: Oxford University Press.

28. Stead, D. (2005). Social Security in Developing Countries. Wider Studies in Development Economics. Oxford: Clarendon Press, 81.

29. Stewart, F. (2009). Income Distribution and Development, retrieved from web 17/09/2018 Towards an Integrated View of Human Rights, Hunger: Social Sciences \& Humanities. International Journal of Clinical Medicine, Vol.7 No.7, July 25, 2016.

30. Tungaraza, F., Mchomvu, A. \& Maghimbi, S. (2002). Social Security Systems in Tanzania: phase 1 overview of social security in Tanzania. Journal of Social Development in Africa, 17 (2): https// dx.doi.org/10.4314/Jsda.v1712.23831

31. Van, G. \& Wouter, M. (2000). The extension of social protection: ILO's aim for the years to come. Seminar on Social Protection, East Hampstead Park.

32. Vobruba, G. (1998). The additional utility of social policy for modernization and Transformation of societies.

33. Von Hauff, M. \& De Haan, A. (1997). Social Security in the International Development Cooperation, Friedrich Ebert Stiftung (Ed). Bonn. 
34. Weininger, E. (2009): Participation, Social Capital, and Intersectoral Problem Solving: African and Asian Cases. In: World Development. Oxford University Press.

35. Wikipedia, Social security - Wikipedia https://en.wikipedia.org/wiki/Social_security 